\title{
'Teach Me This Pedlar's French': The Allure of Cant in The Roaring Girl and Dekker's Rogue Pamphlets
}

\section{MILES TAYLOR}

Dans The Roaring Girl de Dekker et Middleton, ainsi que dans les pamphlets délinquants de Dekker, des citoyens respectables de Londres, fascinés par l'argot des bas-fonds de la société jacobéenne, offrent de payer Moll Cutpurse et des libraires, afin de se familiariser avec ce langage marginal. Aujourd'hui, comme à l'époque, on a soutenu que les dictionnaires d'argot avaient pour fonction de contribuer au contrôle des classes désavantagées par les lecteurs des classes dominantes. Toutefois, ces interprétations ne tiennent pas compte des transformations des discours au sujet de ces dictionnaires durant cette période. Au moment où The Roaring Girl est mis en scène en 1611, date séparée par presque un demi siècle des débuts de l'essor de la littérature délinquante, l'exploration des bas-fonds londoniens ne s'explique pas tant par les moyens qu'elle donne d'anticiper et de prévenir la délinquance en la reconnaissant, que par la pure recherche du plaisir des lecteurs. Dekker lui-même affirme que son exploration des faits et méfaits, et de l'argot de la classe criminelle jacobéenne, est amusante à lire pour tout le monde. La fonction de ces explorations n'est donc pas d'éviter de devenir une victime, mais plutôt d'amuser. Ces plaisirs procèdent aussi du lien entre le langage délinquant et le corps grotesque, objet même d'exclusion et de plaisir.

$\mathrm{T}$

o understand the fascination with cant in Thomas Dekker's Jacobean rogue pamphlets and in The Roaring Girl-his 1611 collaboration with Thomas Middleton-I begin by considering the broader desire of dominant cultures to "break the code" of subcultural speech. The process itself is predictable enough: a subculture emerges; the mainstream culture identifies it; the desire to understand and appropriate leads inevitably to a desire to speak that subculture's coded language. It is a process that we have seen recurrently 
in recent history: from exposing the parlance of jazz musicians in the bebop era, to the latest addition of hip-hop idioms to college dictionaries. It is a curious phenomenon. What explains the desire of the respectable citizen, the embodiment of the dominant culture, to decode the language of an often disreputable, underprivileged, and marginalized Other? Our pleasure in discovering and mastering subcultural idioms was certainly shared by early modern readers and spectators who bought books and attended plays that would teach them "pedlar's French." This essay argues that production of pleasure is the fundamental purpose of cant in The Roaring Girl and Dekker's rogue pamphlets. My argument runs counter to the predominant interpretation of such works in recent criticism, which sees in the appropriation and dissemination of cant a mechanism of control and domination. Yet if, as I contend, the desire to learn cant in the play and in Dekker's rogue pamphlets has pleasure as its primary end, the source of that pleasure remains a problem. I propose not only that the play and pamphlets figure an education in cant as pleasurable, but also that they associate such pleasure with a recovery of parts of the self excluded in identity formation.

The canting scene in The Roaring Girl depicts the pleasure produced by learning a subculture's argot when its eponymous heroine, Moll Cutpurse, serves as mediator between a pair of rogues and a group of respectable merchants and aristocrats. Unable to make sense of the speech between Moll and the hapless vagabonds Tearcat and Trapdoor, Lord Noland asks, "Call you this canting?" The son of a knight, Jack Dapper, responds that he would "give a schoolmaster half a crown a week [to] teach me this pedlar's French" (5.1.177-79). ${ }^{1}$ Moll agrees to stage a demonstration of cant while yet another gentleman, Sir Thomas Long, instructs Trapdoor, "Cant with her, sirrah, and you shall have money-else not a penny" (5.1.183-84). What follows then is a bawdy performance of cant interrupted by exclamations from its respectable auditors of "This is excellent" and "Fine knaves, I' faith" $(5.1 .212,228)$. Nowhere do we find in the scene a suggestion that this performance and subsequent translation of cant serve a utilitarian end; the auditors never suggest that learning the criminal argot will protect them - the reason to learn cant most often cited by the rogue pamphleteers themselves. Rather, there is delight. Their exclamations express pleasure. And as their comments make clear, it is a pleasure worth paying for.

Not surprisingly, most criticism of The Roaring Girl has attended primarily to the significance of Moll Cutpurse as cross-dressing heroine. ${ }^{2}$ While few critics today would agree with Normand Berlin's position that the play's canting scene is "irrelevant and undramatic," it has received little sustained attention in recent scholarship. ${ }^{3}$ Yet like Moll's unique cross-dressing-ex- 
ceptional in that her masculine attire is neither a disguise nor a temporary aberration - the play's focus on underworld argot is unparalleled in the drama of the era. While canting scenes certainly appear in other plays, the careful attention to the particulars of cant and to its translation in The Roaring Girl is singular. Moreover, the play does not merely represent cant; it also imagines the pervasive desire across class divisions to learn it. Thomas Dekker had previously published two prose works reviewing the language of the early modern underworld. His 1608 pamphlet Lanthorne and Candle-light begins with a chapter entitled "The Canter's Dictionary," in which he offers a lexicon of cant relied upon still by editors of The Roaring Girl. Of course, Dekker was not the only early modern writer whose investigations into the criminal subculture focused upon its coded language. Most of the socalled rogue literature of the period includes variations of the cant dictionary. Beginning in 1566, in A Caveat or Warning for Common Cursitors, Vulgarly Called Vagabonds, Thomas Harman includes a subchapter entitled "Here followeth their pelting speech," consisting of what Harman calls "the lewd, lousy language of these loitering lusks and lazy lorels...an unknown tongue but to these bold, beastly, bawdy beggars and vain vagabonds." ${ }^{4}$ Harman's zeal for exposing the "unlawful language" of the criminal subculture takes the form of a presumably representative dialogue between an "upright cove" (or crime syndicate boss) and a rogue, complete with interlineal translation. ${ }^{5}$ Similar dictionaries and dialogues appear in pamphlets by John Awdeley, Robert Greene, Dekker, and "S.R." (Samuel Rowlands), the last of whom promises to supplement Dekker and correct his errors.

The ongoing popularity throughout the period of texts that promised to teach their readers "pedlar's French" confirms that the desire was persistent and wide-ranging. ${ }^{6}$ Yet a difficulty such texts engender is the problem of how reliable are their forays into the subcultural argot. Even if we were to conclude that the London underworld was a highly organized syndicate, structurally hierarchical and complete with schools to instruct in the criminal trade - an idea that enjoys nothing approaching a consensus among historians of early modern London - the delineation of cant in the rogue pamphlets would still be suspect. Rather than "mastering the language of their predators," Dekker's readers were submerged in a fictive world completed by a borrowed lexicon that was itself, by the late sixteenth century, highly conventional. Michael Long has described the early modern characterization of the London underworld as "an inverted mirror image of the 'honest' commonwealth. The rogue fraternity emerges as the antithesis of the commonwealth, as the anti-state." 7 This carnivalesque inversion of the dominant culture must be read as a fictive construct; it too neatly inverts every detail of licit enterprise. Moreover, 
Dekker's reputation as the playwright for the merchant class would seem to trouble the notion that he would write to celebrate its illicit parody.

It is possible, of course, to read his textual explorations of the London underworld as a defense of the prerogatives and values of the citizen as against those criminal elements that threatened them. Yet I think Dekker more typically views a debased and degenerate aristocracy as the ultimate threat to marketplace values. Dekker's sympathies for the marketplace and its denizens tend to express themselves as censure of those parties that abuse their authority and advantage over the average citizen. It would be uncharacteristic for Dekker to "look down" to find antagonists. Moreover, Dekker has a propensity for skewering citizen characters who affect superiority through adopting a polished and genteel manner of speech; it would be equally uncharacteristic for Dekker to demonize cant as a disordered and unruly language.

However, if for Dekker the pretension to superiority produces a language foreign to the citizen, the prevailing critical conception today of the cant dictionaries is to regard them as attempts to marginalize and render foreign the language of the urban underclass. The locus classicus for this argument is Stephen Greenblatt's essay "Invisible Bullets," in which he views textual explorations of cant as analogous to the treatment of Native American languages in exploration narratives. The lower classes, he argues, are rendered as "virtually another people, an alien tribe," with regards to their nonstandard English. ${ }^{8}$ In this view, the cant dictionaries become a way for the dominant culture to record alien voices in order to constitute them as a culture that can be disciplined, corrected, and eventually excluded in the process of national self-definition. Greenblatt, however, elides an important distinction between cant and the figuration of foreign tongues. Unlike the representations of Native American languages, which Greenblatt argues elsewhere are typically characterized by their lack, by a purported absence of authentic language, cant can only be understood as a supplement. ${ }^{9}$ That is, speakers of cant are able to speak standard English, but additionally they are able to "code-switch" and speak a secondary subcultural argot. It is problematic to reduce cant dictionaries and their dramatic counterparts to attempts to "delimit those who spoke nonstandard English into a distinct and hostile subculture," as one recent historian would have it. ${ }^{10}$ Far from being incapable of standard speech, cant speakers are bilingual-linguistic experts with a facility for moving in and out of disparate language situations. As such, they can hardly be considered delimited. Moreover, the respectable citizen's ambition to learn cant is, after all, not a desire to forget his native tongue, but to augment it - to share in the rogue's linguistic competence. 
If we grant that there was something appealing about learning the language of London's early modern urban underworld, something gratifying about supplementing standard English with subcultural idioms, we need to revise the ways that the readers and authors of cant dictionaries have been figured. Greenblatt concludes that "[t]o like reading about vagabonds is to hate them and to approve of their ruthless betrayal." His contention that the aim of these "sinister glossaries" is "to understand and control the lower classes" has been echoed by the majority of critics who have looked specifically at Dekker. ${ }^{11}$ William N. West insists that "the translation of cant...is expansionist and imperialistic."12 Valerie Forman describes the translation of cant as "simultaneous appropriation and exclusion."13 Bracketing the particular nuances of individual arguments, what such interpretations share is the conviction that the gathering and dissemination of cant paradoxically works towards its containment. No doubt there were those who relished the savage treatment of vagabonds and beggars. We know that unsanctioned beggars were burned with brands, their scars a "grisly livery of their indolence."14 (The character Tearcat in The Roaring Girl attempts to hide such punitive burns when he begs without a license.) But we would be mistaken to conclude that Dekker and his audience despised the canting crew. Any diminishment of cant and its speakers in the play and rogue pamphlets is mediated by several factors that problematize such a reading. Instead, the canting scene of The Roaring Girl, as well as Dekker's explorations of cant in the rogue pamphlets, when understood in light of the historical and literary developments this essay will clarify, are surprisingly celebratory of the underworld and its argot. The pleasures these texts promise are never so hostile or aggressive as much recent criticism contends.

I am thus contesting the prevailing critical view that the recording and dissemination of cant is necessarily and intentionally to the detriment of underclass speakers. An alternative that such readings elide is that translating cant may rather work to subvert the dominant language into which it is transcribed. Viewed as a form of carnivalesque discourse, cant may work to subvert its own expropriation. Conventional meanings and valences may be diminished rather than sanctified by a language that works on the margins of the dominant social structures. I am not here substituting a naïve Bakhtinian reading, but rather insisting that any carnivalesque language will have valences that complicate reductive interpretations. In the same moment that an illicit language may reify existing social relations, it may also assert their relativity. Because cant was a permeable dialect, open to a multiplicity of influences and always in process, it embodied the "struggle between variant forms of language" that strict controls of language would elide. ${ }^{15}$ 
Early modern investigations into the language of the underworld also repeatedly emphasize its secrecy, and this secrecy itself could empower the language. Robert Greene, for example, writes that cant was developed toward the end of "obscuring their filthy crafts with these fair colours, that the ignorant may not espy what their subtlety is."16 Indeed, the purported discretion of cant's speakers leads two pamphleteers to describe their own dissimulations in ferreting out their lexicons. Thomas Harman offers that "with fair flattering words, money and good cheer, I have attained to the type... and not without faithful promise made unto them never to discover their names or anything they showed me." 17 Harman breaks both parts of his promise, first in composing a chapter consisting solely of his sources' names and aliases, and second by illuminating their knavery and coded language throughout his text. In a telling moment, Dekker too describes how he came to learn cant:

For my better painting forth these monsters, I once took one of them into my service, being a sturdy, big limbed young fellow. Of him I desired some knowledge in their gibberish, but he swore he could not cant, yet his rogueship seeing himself used kindly by me, would now and then shoot out a word of canting, and being thereupon asked why with oaths he denied it before, he told me that they are sworn never to disclose their skill in canting to any householder, for, if they do, the other maunderers or rogues mill them (kill them). ${ }^{18}$

What we find in Dekker is not only the subtle surveillance necessary for shedding a light on secret societies, but also the institutionalized secrecy within London's underworld with respect to its argot. Dekker cites "Article 8 " of the "Articles of their fraternities": "Thou shalt teach no householder to cant, neither confess anything to them, be it never so true, but deny the same with oaths." 19 Authors of rogue pamphlets typically insist that they jeopardize their own personal safety by publishing this covert lexicon.

I detect in this conventional emphasis a slippage in the fictional constitution of a criminal subculture. Jodi Mikalachki remarks that canting terms seem to advertise criminality rather than to hide it, "almost in the way a brand or other bodily mutilation identified convicted criminals." 20 Indeed, just how hidden is a criminal who speaks in a criminal argot? Its enunciation, even while its meaning remained obscure, would reveal the speaker's identity as a rogue. Allan Futrell makes an observation about twentieth-century criminal argots that is suggestive of something we ought always to acknowledge about early modern cant. We must, he writes,

put to rest the myth that criminals' argots are secret languages used principally to deceive. Argots, while secret or semi-secret, are mainly used as a means of identification by members of the in-group who have knowledge of the sociolect of the subculture. 
However, when a professional criminal converses with members of the dominant culture, he avoids argot and, insofar as he is able, speaks in the social dialect dictated by the social frame in which he finds himself. ${ }^{21}$

This observation corrects a lapse in recent criticism that uncritically reiterates an error common in the early modern rogue literature - the claim that cant ought to be understood primarily as a technique used by rogues in their unlawful deceptions of law-abiding citizens. ${ }^{22}$ Learn the language or "else you may be marvelously mistook," Greenblatt argues, echoing Robert Greene's claim that cant's function is to conceal criminal acts. ${ }^{23}$ The Roaring Girl portrays cant in a more accurate light, I believe, in that its performance of cant occurs only after Tearcat and Trapdoor are outed as rogues. Note the crucial difference: once identified as vagabonds, they can engage in a bout of canting; only after their begging scheme is frustrated does the argot surface.

As the play resists figuring cant as a threat to the dominant culture, substituting pleasure for utility as the motivation for learning it, Dekker's depiction of canting in The Roaring Girl is not so much ambivalent as celebratory. The only ambiguity that the play registers about cant concerns Moll's accumulation of its secrets. If she would not be tainted by her knowledge of cant, she must explain "how thou camest to the knowledge of these nasty villains" and answer the question "why do the foul mouths of the world call thee Moll Cutpurse?-A name, methinks, damned and odious" (5.1.311-14). Moll defends her knowledge of the canting crew by recourse to the same justification employed by the rogue pamphleteers: she studies them "to bring to shame / Such rogues, and in that stream met an ill name" (5.1.321-22). If cant itself is delightful to learn, there is still something morally questionable about learning it; paradoxically, to learn cant is to experience pleasure even as it marks the adept as suspect. Moreover, the satisfaction of learning the language of the London underworld is again coupled with the imagined disruption of that subculture - one learns cant in order to bring its speakers to shame. Typical for rogue literature are these competing pulls toward fascination and revulsion.

Moll's position as mediator and translator is, of course, Dekker's own position. If her knowledge of cant is incriminating, so too is Dekker's. There is a double-edged quality to knowledge of cant and a corresponding anxiety that must be dispersed. In part, I am arguing, this anxiety is relieved in statements of hostility toward the object of knowledge. Cant is coded as hateful to restore its speaker's equilibrium, but to do so cannot efface the signs of pleasure produced by its acquisition. Moll's facility at translation, it has been argued, "allows her a certain license to move between the rogues of the London suburbs and the gentlemen and lords who visit the city." 24 As 
bilingual speakers code-switch in the move from one language situation to another, she is able to move freely among and between the disparate classes represented in the play. She is a kind of linguistic voyager, able to transgress the borders of licit and illicit speech. Such liberty corresponds exactly with her more famous transgressive apparel. Dressed in masculine apparel, Moll enjoys a kind of free play across gender conventions; versed in cant, she enjoys an analogous autonomy to move between oppositional linguistic domains. The cost of linguistic freedom is the renunciation - both by Moll and by Dekker - of the disadvantaged language itself. Yet if renouncing cant is essential in its acquisition, the language cannot be so easily contained once it is published or spoken aloud. To move between these well-divided language spheres is to render them permeable to one another. ${ }^{25}$

In a prefatory poem to Dekker's Lanthorne and Candle-light, a defender asserts that though Dekker writes the "true anatomy" of the criminal subculture, readers ought not to suspect the author of being a friend of the underworld: "Then on thy plainness let none lay reproof, / Thou tak'st sin's heighth, as men do stars, aloof." 26 But Dekker's aloofness is belied by his tale of how he learned cant from one whom he had taken into his service. It is best "to behold them afar off," but to learn and relate their language requires proximity. ${ }^{27}$ The author's dilemma-how to infiltrate the underworld in order to record its language without being tainted by that familiarity-in turn implicates Moll herself along with Dekker's readers and auditors. In learning cant, will the identities of Dekker's audiences be altered by a newly-acquired fluency in the forbidden language? One senses the anxiety that rogue literature does not protect respectable citizens so much as instruct them in how to be rogues themselves. "If from hence a knave more cunning grows," a second prefatory poem frets, "That spider sucks but poison from thy rose."28 The explicit apprehension that rogue literature may initiate a "spider" into the criminal arts, combined with the textual disclaimer of Dekker's proximity to the underworld, suggests a deeper concern about how encounters with a criminal subculture might transform authors, readers, and audiences.

It is true that the earliest pamphlets, those of Awdeley and Harman in the $1560 \mathrm{~s}$, make explicit their mission of exposing cant that "thereby the justices and shrieves may in their circuits be more vigilant to punish these malefactors." 29 In the earliest examples of rogue literature, the expressed ends are utilitarian and specifically juridical - the authors imagine wealthy citizens and civic authorities as their readers, and this audience's education in cant will engender, respectively, self protection and better law enforcement. Later works, however, introduce a new inducement to read: in 1591, Robert Greene describes his Notable Discovery of Cozenage as "delightful," and 
in a subsequent pamphlet, The Second Part of Cony-Catching, he promises that "if you read without laughing, Ile give you my cap for a Noble." 30 In Lanthorne and Candle-light, Dekker suggests of the criminal class that "to behold them afar off may delight you," and in the same year he describes his The Belman of London as "delightful for all men to Reade." 31 Thus, the later rogue pamphlets are expressly interested in the production of pleasure in a way their precursors never are. We need to ask why the concealment and subsequent discovery of cant come eventually to produce delight.

One explanation is that cant is rendered erotic through its construction as a form of secret knowledge that resists dissemination. In a recent essay, William N. West argues that the secrecy of cant renders language itself an object of desire. "Instead of concealing the content of criminal conversations," he states, "cant begins to look like the determined production of some area of secrecy or mystification." 32 For West, the content of the language is far less significant than its secrecy. In this reading, it does not matter what cant expresses; what matters is that its veiling engenders the desire to unveil, a desire satisfied by works like The Roaring Girl and Dekker's rogue pamphlets. West's insights are indispensable, but what such a reading elides is the historical transitions within cant glossaries from the 1560s into the Jacobean era. Cant is always already "secret" - even as it becomes conventional-but the production of pleasure as the explicit, central function of learning cant is a late development. Awdeley and Harman never promise delight, but a generation later Greene and Dekker do.

A related problem is suggested by the fictive nature of late rogue pamphlets in general. "S.R." (Samuel Rowlands) begins his Martin Markall, Beadle of Bridewell (1610) with a sustained attack on Dekker's credibility. He condemns The Belman of London specifically for "the errour in some places in setting downe olde wordes used forties yeeres agoe" and suggests that Dekker "enlarged his Dictionary (or Master Harmans) with such wordes as I thinke hee never heard of." 33 A review of Harman and Dekker confirms this critique; Dekker's canting dictionary is borrowed wholesale from Harman's 40-year-old pamphlet. Rowlands, then, calls our attention to a crucial detail: Dekker's tale of surveillance, his depiction of his hired man's resistance to rehearsing his knowledge of cant, are merely fictions that only barely conceal his literary borrowings. That Dekker's lexicon is plagiarized and his eyewitness account invented underscores the caution we need to take in asserting that his texts represent social realities. Indeed, the assertion in early modern prose fictions that they are factual and not merely invention is itself a convention in the development of fictional art. Dekker relies on previously published works and not merely (or even necessarily) first-hand experience in fleshing 
out his canting crew, and his particular borrowings from Harman indicate that the unveiling of cant's secrets has moved from purported utility to literary convention. Pleasure is derived in part from illuminating that which the author marks as obscured (as opposed to that which he finds already obscured), and yet the more interesting problem remains. We need yet to clarify why an author like Dekker would locate the hidden language that is the object of desire at the disadvantaged margins of culture; why he would put the secret in the mouth of the excluded and marginalized Other.

In The Seven Deadly Sinnes of London (1606), Dekker writes in a "reformatory spirit" of his pity for wronged prisoners and entreats for mercy from the true offenders - spiteful creditors. ${ }^{34}$ In 1609, the year after he wrote Lanthorne and Candle-light and The Belman of London, Dekker published $A$ Prayer for a Prisoner on the plight of debtors. Over a period of 20 years, he wrote or co-wrote a number of pamphlets decrying both the vindictiveness of creditors and the roguery of constables and warders. Unlike with his canting glossaries, we can be certain that his treatment of early modern prisons was based on first-hand experience. Dekker himself was confined as a debtor at the Poultry Counter in 1598; he was discharged only when Henslowe paid the two pound fee for his release - a sum indicating Dekker's dire poverty. In the following year, he was again confined, and again Henslowe paid the fee - three and a half pounds - for his release. In Villanies Discovered (1616), Dekker admits that he himself had been imprisoned more than three years, while in Dekker His Dreame (1620) he claims that his total imprisonment was closer to seven years. ${ }^{35}$ One reason, then, that Dekker locates the secret worth knowing at the disadvantaged margins of society is his exceptional awareness of the persecution faced by vagabonds and beggars. For Dekker, the urban poor were not an alien culture to be brought to discipline, but the victims of a pitiless economy and a lawless justice system. By virtue of their marginalization - which was his own at times - they best can reveal the injustices to which privileged subjects may be blind. Too, because they are outside the dominant culture, they best can parodize its ideology. Their marginalization, which is of course the effect of oppression, is also their distinctive power.

Moll Cutpurse is, I have argued, the marginal figure par excellence. She is at once inside and outside both the rogue subculture and the dominant culture. She is able to shuttle back and forth between the two worlds in a way unique to her within the play. Beyond her masculine apparel, what marks her distinctiveness is her titular designation. As Jean Howard succinctly states, "To be a roaring girl is to have one's mouth open." 36 It is as much Moll's facility in speech that makes her interesting as it is her dress - the play's title 
evokes her talk, after all, not her doublet. If cultural mores required that a woman be known and unknowing, Moll doubly subverts gender expectations. While characters assume they can know her, she always transcends their expectations. More significantly, she confounds her gentleman attendants with her knowledge of the London underworld. By virtue of her capacity to move freely between licit and illicit worlds (and words), her perspective has priority. Specifically, her ability to code-switch between cant and standard English marks her as radical in two senses: her linguistic authority is both universal and subversive. We're mistaken to conclude that the effect of Moll's translation of cant is to render it innocuous, though, since Dekker resists depicting cant as a menace. ${ }^{37}$ Trapdoor and Tearcat are harmless beggars merely. But their exit is succeeded by the entrance of real criminals, a gang of cutpurses, distinctive in their fine clothes. Their apparel deludes the gentlemen accompanying Moll into assuming these are men of their own class, and interestingly the cutpurses never speak cant but always the standard English of the play. The juxtaposition of these scenes suggests that while cant is fascinating, it is not something to fear - the real danger, the successive vignettes suggest, is more likely to come in the language and apparel of respectable citizens. Because the cant speakers engaged by Moll are figured as hapless clowns rather than accomplished villains, cant becomes a playful carnivalesque language of misrule, and its subversive undercurrents remain intact.

What makes possible cant's subversive potential, in other words, is that its speakers are already imagined to be rendered harmless. The discovery of the already subjugated Other is constitutive of middle-class identity formation, and while the gentlemen in the play are not themselves members of the citizen class, Dekker's audiences were. Cant in the play and the rogue pamphlets has been called an "anti-language" spoken by "misshapen undesirables" and can be understood fruitfully as analogous to the grotesque body. ${ }^{38}$ Cant produces linguistic difference, and that difference can work in two registers at the same time-subversion and containment. It would be mistaken to reduce the effect of cant to one or the other pole. We see in The Roaring Girl, as a case in point, a simultaneous repugnance and fascination with cant. Jack Dapper's offer to pay a schoolmaster half a crown a week to teach him to cant produces its subsequent performance, but near its end, he complains that the "grating of ten new cart-wheels, and the grunting of five hundred hogs coming from Romford market cannot make a worse noise than this canting language does in my ears" (5.1.229-32). If there is fascination with the vulgar and the marginalized, there is also a corresponding revulsion. Even as it is described as mere ugly noise, cant is worthy of imitation by the respectable gentlemen within the play. ${ }^{39}$ 
Stallybrass and White provide a definition of transgression that well suits the argot of a criminal subculture; they identify transgression in "any act of expressive behavior which inverts, contradicts, abrogates or in some fashion presents an alternative to commonly held cultural codes, values and norms." Moreover, they suggest that the Bakhtinian notion of the grotesque body is fundamental to the method by which transgressive outsiders would be excluded. ${ }^{40}$ We witness just such fashioning in the cant dictionaries, which figure the underworld as grotesque by delineating a language that focuses on the mouth, belly, genitals, and buttocks. In Martin Markall, for example, "S.R." cites as a typical phrase "Your prat whids romely," which he translates as "You fart lustily." 11 The glossaries all share this fascination with the body, focusing almost exclusively on cant equivalents for the language of eating, drinking, scatology, and sex. Buttocks are a "prat"; a bed is a "libbege"; alcohol is "bouse"; bread and cheese are "pannam and cassan"; sexual intercourse in "wapping" or "niggling." 42 To lie down and sleep, "S.R." informs us, is to "couch a hogshead"; a mouth is a "gan"; feces is "jeer"; urine is "lage." 43 Cant, then, is figured as grotesque, bawdy, permeable - opposed to any repressive language of official culture.

In its constant recourse to deep-rooted taboos, cant may also be seen as implicating its speakers through an association with all things forbidden, especially sexual proscriptions. I would argue, however, that cant works rather to bring language down to earth, to pierce the pretension of the language of classical bodies. In a telling moment, Moll refuses to translate Trapdoor's most bawdy expression: "'And then you shall wap with me, and I'll niggle with you,'-and that's all" (5.1.204-05). Her reluctance here to translate prompts Sir Beauteous to persist, "Nay, nay, Moll, what's that wap?" Jack Dapper further prods her: "Nay, teach me what niggling is; I'd fain be niggling" (5.1.206-07). Because the phrase remains untranslated, it is repeated again and again, until finally Trapdoor tells them that to "wap" and "niggle" is the same as "fadoodling" (5.1.211). Moll's refusal to translate here only emphasizes the sexual nature of cant. Its most explicitly sexual terms, then, are never translated in the play, as if to do so would be impossible. Because the idioms can only be rendered into another slang term, the play suggests that one must learn the argot to experience and enjoy this free play of language. In the context of the scene, and as Jack Dapper's declaration that he would "fain be niggling" makes clear, the terms are perfectly understood. The sexualized language of cant thus penetrates the official language intact, in the end without translation.

We can infer that once such language is excluded by the dominant culture, it may well be retrieved as an object of desire. As excluded Others "play 
a symbolic role in bourgeois culture out of all proportion to their actual social importance," a similar process occurs with their argot. Once the language of high culture is structured in relation to the low, there is "repugnance and fascination"; the language excluded is both "reviled and desired." "The later dictionaries of cant, then, emerge at a markedly different stage in the process of identity formation. Once an official language has been constituted in part through the identification and exclusion of underworld argots in the early dictionaries, the recurrent and redundant "discoveries" of cant in later texts suggest the canting glossary's shift from the utilitarian to the symbolic. One measure of how much cant came to be an object of desire is its extensive appropriation by respectable readers. "Prat" entered mainstream English (as in "pratfall"), and the cant term for hose, "drawers," is still in currency. Other modern traces of the language of the London underworld remain in cant terms like "bouse" (or booze), "peckish" (hungry), "filch" (steal), "duds" (clothes), "foist" (to pick a pocket), "plant" (to hide), and "tip" (to give). But these are only modern resonances; the early modern appropriation of cant was much more comprehensive. "S.R." comments upon the widespread dissemination of cant that the dictionaries had engendered: "These volumes and papers now spread everywhere," he writes, "so that every jack-boy can now say as well as the proudest of that fraternity: 'Will you wap for a win, or trine for a make?," which I translate as "Will you have sex for a penny or hang for a half-penny?" 45 Evidently, the cant glossaries supplied a lexicon desirable for everyone, from the lowliest menial laborer to the aristocrats of The Roaring Girl, to learn. This is not to suggest that there were not other ways, other discourses, for speaking the same content, but rather that the pleasures associated with the content produced a desire to accumulate new forms of expression.

What I am suggesting, too, is that the practice of appropriating the language of a marginalized subculture may be less about exclusion or negation than the playing out of a "complex hybrid fantasy" of self and excluded Other. ${ }^{46}$ Individuals within the dominant culture constitute identity by constructing borders which demarcate its boundaries - what falls outside these borders but still exists within the individual must be repressed to maintain the subject's integrity. But that which is both recognized as self and excluded as Other must frequently return as an erotically charged element of the fantasy life. Often, and specifically in the case of the language of the early modern underworld, that which is excluded in the higher, more respectable forms of discourse is the grotesque - the realm of lower bodily processes. But everyone eats, drinks, defecates, urinates, passes gas, and copulates. Bodily experience belies the prescribed ideal of the classical body-static, without 
orifices, unblemished, never in process. The fascination with the grotesque, then, can be actively produced by its suppression. The proliferation of cant glossaries and the manifest and widespread desire to learn their "unlawful language" can be understood as symptomatic of a subversive desire: to speak the "unknown tongue" is to give voice to those elements repressed by identity formation. Again, it would be a mistake to suggest that similar words, similar slang terms for like referents, were not also available for acquisition. It rather underscores my argument to note that a language for designating the carnivalesque is never complete; speakers are voraciously accumulative of such language. Moreover, cant itself is uncanny, at once familiar and unfamiliar. The "complex hybrid fantasy" becomes a fantasy of re-integration, a desire to make bodily experience and the socially-constructed body cohere. This fantasy can be acted over endlessly with each new acquisition.

While I am suggesting that Dekker's cant glossaries and the canting scene of The Roaring Girl are subversive, I do not conclude that they are therefore progressive. Discovering desire in the excluded Other may in fact be constitutive of identities within the dominant culture. That desire, and its satisfaction through learning the coded language of the dispossessed, may in turn transform the identities of those students of the underworld. However, such transformations do nothing to challenge the original sublimation of the Other, his figurative exile to a world "under" the world we ourselves inhabit. Instead, as we see in the acquisition and dissemination of cant, desire for those on the margins can easily lead to their commodification. By making cant a commodity that authors, readers, and audiences - and of course the gentlemen within The Roaring Girl - pay to acquire, the objectification of the underworld and its denizens may only be reinforced.

Moll frustrates Trapdoor in his attempt to beg money posing as maimed soldier, but he is promised payment for a performance of cant: "Cant with her, sirrah, and you shall have money" (5.1.183-84). The rogue pamphleteers confessed that they bribed canters to unveil their secrets; the popularity of their pamphlets produced income for the writers. We can well agree with Paula Blank's remark that cant had become "a language that generated profit not only for the rogues who allegedly spoke it, but for the authors who appropriated it." 47 In a play preoccupied with commodities, cant enters the marketplace and is exchanged for an equivalent amount of money. Of course, the play itself is a commodity, and the playwrights themselves produce language for pay. Moreover, there is an analogy between the canting crew and the players who represent them, each performing language for their livelihood, and each under the force of the Vagabond Act of 1572. If cant becomes a commodity, perhaps the valence of its commodification is less disquieting in 
the theatrical context, where it is one commodity couched in another commodity of language.

We should remember that even as it becomes a commodity, cant yet engenders the pleasure that comes from adopting the perspective of marginalized subjects. Once cant is figured as entertainment rather than as an illicit behavior to eradicate, it subverts rogue literature's purported utility. Rather, there is admiration for the rogue's wit and delight at his exploits. There are few dramatic tropes more common to the period than the depiction of knaves conning gulls, and our sympathies are overwhelmingly with the knaves in such instances. We laugh with Sir Toby at the credulity of Andrew Aguecheek, and with Volpone and Mosca at the witlessness of their dupes. The London underworld is yet more appealing, in that its cony-catchers are not so respectfully situated. Even while it keeps in mind the criminality intrinsic to such figures, the audience acknowledges in its laughter, in its delight, the perspective of the most disadvantaged characters, "the utterances of the unauthorized." 48 It is the pleasure of the world-turned-upside-down, if only transiently.

Critics have discerned a nostalgic quality to the depictions of cant and its speakers, and this should be expected when we consider that Jacobean instances like Dekker's in particular offer a voice already repressed and now returned as an object of fascination. ${ }^{49}$ Certainly, rogue pamphlets from the 1560 s work in a different register than Dekker's Jacobean pamphlets and play. Thomas Harman establishes the conventions that later writers borrow and reinscribe, but when the conventions of the genre are taken into account, the remainder in Jacobean works is a kind of delight in the canting crew, a delight that perhaps romanticizes cant as something already lost. The fictiveness of the late rogue pamphlets signifies that the time for their purported utility in suppressing actual criminals has passed.

What is produced by Dekker's canting glossaries and the canting scene of The Roaring Girl is "linguistic consciousness," the awareness of language as language, and as such these texts work against the myth of a completely unified language. ${ }^{50}$ In place of that myth, and as a result of the interanimation of official and unofficial forms of speech, language becomes open and multiple. The dissemination of cant within the play and through the prose pamphlets allows readers and spectators to adopt the language and manners of the Other, and this adoption of a marginalized language in particular renders the subject's own language permeable, as the historic traces of cant that survive today in standard English illustrate. The analogy to theater is obvious: speaking in the language of another is "the very raison d'etre of acting and the reason for the audience's interest in what an actor does." 51 The performance of cant in The Roaring Girl merely reproduces that which 
theater always produces - the free play of language and social roles. The pleasure of learning cant is in that sense indistinguishable from the pleasure of staging or attending a play. Cant's appeal is even broader, however, in that it allows those who master it access to a kind of urban authenticity beyond the margins of middle-class respectability. Janet Sorenson writes of a later moment that "the true national insider must perpetually keep up with phrases that might pop up anywhere (but most often in urban centers)." 52 I believe this constitution of insider status through acquaintance with the language of urban centers is at work in Dekker's pamphlets and play as well. Beyond the carnivalesque pleasure associated with learning an illicit tongue, beyond the theatrical pleasure of adopting temporarily the language of the Other, there is always the appeal of being inside the urban con, no longer subject to its duplicities, however fictive. Finally, we respectable citizens suspect that other speakers are having more fun, are more in the know, so we set our tongues to their speech, hoping to relieve our own boredom and anxiety.

\section{Le Moyne College, Syracuse, NY}

\section{Notes}

The author gratefully acknowledges the support of Dr. Elizabeth Hayes, who through the auspices of Le Moyne College's O'Connell Professorship made possible the research and writing of this essay.

1. All quotations from the play are from The Roaring Girl, ed. Paul Mulholland (Manchester: Manchester University Press, 1987).

2. See, for example, Stephen Orgel, "The Subtexts of The Roaring Girl," Erotic Politics: Desire on the Renaissance Stage, ed. Susan Zimmerman (New York: Routledge, 1992), pp. 12-26; Jean Howard, "Sex and Social Conflict: The Erotics of The Roaring Girl," Erotic Politics, pp. 170-90; Mary Beth Rose, "Women in Men's Clothing: Apparel and Social Stability in The Roaring Girl," English Literary Renaissance 14 (1984), pp. 367391; and Marjorie Garber, "The Logic of the Transvestite: The Roaring Girl (1608)," Staging the Renaissance: Reinterpretations of Elizabethan and Jacobean Drama, ed. David Scott Kastan and Peter Stallybrass (New York: Routledge, 1991), pp. 221-34.

3. Normand Berlin, The Base String: The Underworld in Elizabethan Drama (Rutherford: Fairleigh Dickinson University Press, 1968), p. 117.

4. Thomas Harman, Caveat, in The Elizabethan Underworld, A.V. Judges, ed. (London: Routledge, 1930), pp. 113-14.

5. Harman, p. 62.

6. William West identifies "dozens of glossaries, manuals, and cony-catching pamphlets... all purporting to reveal the mysteries of cant" (232). "How to Talk the Talk, or, The Work of Cant on the Jacobean Stage," English Literary Renaissance 33 (2003), pp. 228-51.

7. Michael Long, "Transgression and Cultural Taboo: Constructing the Criminal in English Renaissance Rogue Literature," Cahiers Elisabéthains: Late Medieval and Renaissance Studies 54 (Oct 1998), p. 10. 
8. Stephen Greenblatt, "Invisible Bullets," in Shakespearean Negotiations (Berkeley: University of California Press, 1988), p. 48. Other critics who concur with this viewpoint include West (cf. note 6) and Valerie Forman in her "Marked Angels: Counterfeits, Commodities, and The Roaring Girl," Renaissance Quarterly 54:4 (2) (2001 Winter), pp. 1531-60.

9. Greenblatt makes the argument about indigenous languages as non-languages in Learning to Curse: Essays in Early Modern Culture (New York: Routledge, 1990), esp. p. 19ff.

10. John McMullan, The Canting Crew: London's Criminal Underworld, 1550-1700 (New Brunswick, NJ: Rutgers University Press, 1984), p. 96.

11. Greenblatt, "Invisible Bullets," pp. 52, 49. Twenty years before Greenblatt, Berlin insisted on Dekker's "genuine hatred for criminals" in his rogue pamphlets (p. 32).

12. West, p. 240.

13. Forman, p. 1554.

14. Craig Dionne, "Playing the 'Cony': Anonymity in Underworld Literature," Genre: Forms of Discourse and Culture 30:1 (Spring-Summer 1997), p. 38.

15. Michael Bristol, "Carnival and the Institutions of Theater in Elizabethan England," English Literary History 50:4 (1983): 638.

16. Robert Greene, Notable Discovery, in The Elizabethan Underworld, p. 136.

17. Harman, p. 62.

18. Dekker, O Per Se O, in The Elizabethan Underworld, p. 367.

19. Dekker, O Per Se O, pp. 377-78.

20. Jodi Mikalachki, "Gender, Cant, and Cross-Talking in The Roaring Girl," Renaissance Drama 25 (1994), p. 120.

21. Allan W. Futrell, "Introduction," Language of the Underworld (Lexington: University Press of Kentucky, 1981), p. 11.

22. See West, who claims that "cant relies on secrecy to prey on the legitimate world" (p. 239).

23. Greenblatt, "Invisible Bullets," p. 58.

24. Mikalachki, p. 119.

25. My argument here is indebted to John Gillies's discussion of the ontological threat posed by the voyager in Shakespeare and the Geography of Difference, (Cambridge: Cambridge University Press, 1994), p. $3 \mathrm{ff}$.

26. Dekker, Lanthorne, in The Elizabethan Underworld, p. 316.

27. Dekker, Lanthorne, p. 314.

28. Dekker, Lanthorne, p. 316.

29. Harman, p. 62.

30. Quoted in The Elizabethan Underworld, pp. 135, 152.

31. Quoted in The Elizabethan Underworld, pp. 314, 302.

32. West, p. 247.

33. Quoted in Paula Blank, Broken English: Dialects and the Politics of Language in Renaissance Writings (New York: Routledge, 1996), p. 58. 
34. Phillip Shaw, "The Position of Thomas Dekker in Jacobean Prison Literature," Publications of the Modern Language Association of America 62 (1947), p. 373.

35. Shaw, p. 378.

36. Howard, p. 181.

37. West argues that Trapdoor and Tearcat are "rendered harmless" when Moll "exposes [cant's] hidden meanings [and] diffuses its threat" (239). However, the sequence of events within the scene belies this interpretation. Moll diffuses the two unsanctioned beggars prior to their performance of cant; cant is never depicted as contributing to any threat.

38. Deborah Jacobs, "Critical Imperialism and Renaissance Drama: The Case of The Roaring Girl," Feminism, Bakhtin, and the Dialogic, ed. Dale M. Bauer and Susan Jaret McKinstry (Albany: State University of New York Press, 1991), p. 78.

39. In an otherwise excellent essay about the place of canting dictionaries in the eighteenth century, Janet Sorenson claims that earlier texts of the sixteenth and seventeenth centuries never posit cant as "worthy of playful imitation," an approach to cant that only emerges, she argues, in the later eighteenth century. The Roaring Girl belies that claim, but her notion of cant as something "worthy of jocular imitation by fashionable men" is a useful way to figure its acquisition in the play (438): Sorenson, "Vulgar Tongues: Canting Dictionaries and the Language of the People in Eighteenth-Century Britain," EighteenthCentury Studies 37:3 (Spring 2004), pp. 435-54.

40. Peter Stallybrass and Allon White, The Politics and Poetics of Transgression (Ithaca: Cornell University Press, 1986), pp. 17, 22.

41. Quoted in The Elizabethan Underworld, p. 406.

42. Harman, pp. 114-15.

43. Quoted in The Elizabethan Underworld, pp. 407-08.

44. Stallybrass and White, pp. 20, 4.

45. Quoted inThe Elizabethan Underworld, p. 386.

46. Stallybrass and White, p. 193.

47. Blank, p. 58.

48. Pamela Brown, "Laughing at the Cony: A Female Rogue and "The Verdict of the Smock," English Literary Renaissance 29 (1999), p. 203.

49. Critics who see underworld literature as characterized by nostalgia include Dionne, esp. p. 34; Brown; and Jean-Christophe Agnew, Worlds Apart: The Market and the Theater in Anglo-American Thought, 1550-1750 (Cambridge: Cambridge University Press, 1986), esp. p. 66.

50. Mikhail Bakhtin, "From the Prehistory of Novelistic Discourse," Modern Criticism and Theory, ed. by David Lodge with Nigel Wood (New York: Longman, 2000), pp. 104-36.

51. Bristol, p. 649.

52. Sorenson, p. 448. 